\title{
Changing the Nature of Our Constitutional Default: The Fight for a Right to a Healthy Environment
}

Katelyn Joanna Jones*

\begin{abstract}
The convergence of environmental law, constitutional law, international law and human rights in the formation and steady acceptance of environmental constitutionalism is a relatively new occurrence. Environmental rights are included in 147 of the 193 national constitutions worldwide. Despite this collective commitment to environmental protection, Canada's polluted air, disappearing forests, contaminated waterways and the human health consequences associated with such ills continue to receive no constitutional protection. If the existing legal framework is unable to protect this right, Canadians will demand express recognition of it. Silence - as our constitutional default - is an inadequate response to the growing need for the right to a healthy environment to receive codification.
\end{abstract}

Keywords: constitutional law, environmental law, the right to a healthy environment, airborne pollutants, Canadian environmental policy

"The environment is humanity's first right."

- Ken Saro-Wiwa, 19951

The convergence of environmental law, constitutional law, international law and human rights in the formation and steady acceptance of environmental constitutionalism is a relatively new occurrence. The environment as a subject of legal rights discourse is not, however, a new idea. The entrenchment of a constitutional right to the environment has in fact become a global norm.
As of 2012, environmental rights are included in 147 of the 193 national constitutions worldwide, with ninety-four explicitly entrenching the right to live in a healthy environment.2

Canadian environmentalists have long lobbied for such a right. Provinces and territories have begun to recognize statutory environmental rights, illustrating the already existent legal, political and symbolic recognition of the right to a healthy environment. Despite this collective commitment to environmental protection, Canada's

Sawo-Wiwa: http://remembersarowiwa.com/background/the-lifeof-ken-saro-wiwal. Accessed 16 March 2015.

2 David Boyd, The Right to a Healthy Environment: Revitalizing Canada's Constitution (UBC Press, Vancouver: 2012), 88.

\footnotetext{
*College of Law, University of Saskatchewan, Saskatoon, SK, Canada
}

Correspondence: kjjo78@mail.usask.ca 
polluted air, disappearing forests, contaminated waterways - and the human health consequences associated with such ills - continue to receive no constitutional protection.

The purpose of this paper is to analyze the legislative and judicial framework surrounding the entrenchment of the constitutional right to a healthy environment in Canada.3 While acknowledging the challenges to be overcome in achieving constitutional status, I begin from the premise that Canada should recognize an express and substantive right to the environment. This assertion is grounded in the increasing national and international pressure to recognize this right, the inherent limits of a legislative base to environmental rights, and the Supreme Court of Canada's continued rejection of an implicit right to the environment in the existing rights and freedoms established in the Charter of Rights and Freedoms.4

Part I begins with a discussion of the value of constitutionalism and the advantages to the entrenchment of the right to a healthy environment. I examine the nature and scope of this right in both its general and specific terms. I then discuss whether the right to a healthy environment has achieved status as a human right globally, and what this means for its eventual recognition in Canada.

Part II presents a case study relating to a Notice of Application filed to the Ontario Divisional Court by residents of Sarnia, Ontario. This action highlights the growing concern related to adverse human health impacts from exposure to industrial contaminants. It exemplifies the need for the right to a healthy environment to ensure citizens have adequate legal recourse to protect themselves from the harmful effects of environmental contaminants. Changing the elusive nature of our constitutional default is merely the next step in entrenching environmental constitutionalism in Canada.

Part III examines the gaps in the current legal framework to demonstrate that Canadians need a constitutionally-recognized right to the environment. It starts with a discussion of the inherent limits of a legislative basis for environmental rights. In assessing the limits of provincial and federal environmental statutes, I examine the effectiveness of Ontario's Environmental Bill of Rights $(\mathrm{OEBR})_{5}$ and the proposed Canadian Environmental Bill of Rights through Bill C-634.6 I then discuss the Supreme Court's continued hesitancy to recognize an implicit

\footnotetext{
${ }_{3}$ For the purposes of this paper, the "right to a clean environment" and the "right to a healthy environment" will be used interchangeably.

${ }_{4}$ The Canadian Charter of Rights and Freedoms, Part I of the Constitution Act, 1982, being Schedule B to the Canada Act 1982 (U.K.), 1982, C 11 [Charter].

${ }_{5}$ Environmental Bill of Rights, 1993 SO 1993, c 28 [OEBR].

6 "Legisinfo: C-634, An Act to Establish a Canadian Environmental Bill of Rights," Parliament of Canada, $41^{\text {st }}$ Parliament, $2^{\text {nd }}$ Session [Bill C634].
}

environmental right in both section 7 and section 15 of the Charter to show that silence - as our constitutional default is an inadequate response to the growing need for the right to a healthy environment.

\section{Part I: Changing Our Constitutional Default}

Despite the proliferation of environmental constitutionalism over the past 20 years, the need for a clearly defined environmental right and its corresponding duties remains largely unarticulated.7 The right to a healthy environment has received particularly varying definitions. As environmental quality continues to deteriorate both globally and nationally, the preservation of healthy human environments through a constitutionalized right hinges on the improvement of this definition. Only upon examination of the specific and determinative definition of a human right, and a corresponding examination of the rights and responsibilities attached to the environment, can the right to a healthy environment be clearly and fully conceived.

This section lays out the value of constitutionalism, what it would mean to have a "right" to a healthy environment, and how substantive environmental rights could be given legal effect. While proponents argue that this right has already achieved the status of an internationally recognized human right, 8 critics argue it is too ambiguous or avow its standing as a social value but not a legal principle.9 This section concludes with a discussion of whether the right to a healthy environment has achieved status as a human right globally, what is involved in a right being recognized as a human right, and what this means for its recognition in Canada.

The Value of Constitutionalism

Constitutions define and distribute the powers that can be exercised by government, and also demark the limits of these powers. They describe individual and group rights, and prevent political overreach when other constraints on power have failed.10 Given its role in defining the relationship between the state and its citizens, the advantages of constitutional environmentalism are plentiful. It can give individuals procedural rights, hold government officials accountable, require action or forbearance, promote values, and establish new legal norms.11 It also encompasses almost

7 Elaine Hughes and David lyalomhe, "Substantive Environmental Rights in Canada," Ottawa Law Review 30, no. 2 (1998-99): 231.

8 Noralee Gibson, "The Right of a Clean Environment," Saskatchewan Law Review 54, no. 5 (1990): 5.

g lbid., 9 .

${ }_{10}$ Gordon J. Schochet, "Introduction: Constitutionalism, Liberalism, and the Study of Politics," in Nomos XX 1, eds J. Roland Pennock and John W. Chapman (New York University Press, 1979), 5.

${ }_{11}$ James R. May and Erin Daly, Global Environmental Constitutionalism (Cambridge University Press: New York, 2015) at 49. 
every tool of law available, thus providing a truly holistic approach to environmental protection. Furthermore, the fact that "constitutions have always been a standard of legitimacy" ${ }_{12}$ establishes it as a mark of authority and validity over state organization and the corresponding rights owed to citizens.

As it stands, the Charter protects fundamental freedoms, democratic rights, mobility rights, legal, equality, language and Aboriginal rights. Since the Constitution is the supreme law of Canada, all other laws must be consistent with these rights. While federal and provincial statutes are important mechanisms for environmental protection, a legislative basis for environmental rights is inherently limited because they can be repealed. The substance of statutory and constitutional rights may seem similar, but David Boyd, a leading academic in the field of environmental constitutionalism, asserts that they are "like lions and housecats - related, but dramatically different in degrees of strength." ${ }_{13}$ Environmental constitutionalism thus offers itself as "an essential node in the web of national management of the environment." ${ }_{14}$

Proponents argue that entrenching the right to a healthy environment would clarify governments' responsibilities over the environment and contribute to improving environmental performance of legal and extralegal outcomes.15 Boyd asserts that the right would provide a stimulus for enacting stronger environmental laws; bolster implementation and enforcement of existing environmental laws, regulations and policies; increase accountability between governments and individuals; create a level playing field with other social and economic rights in decision making; and foster a sense of environmental justice by protecting the right of vulnerable Canadians to a healthy environment. 16

The absence of a constitutionalized environmental right also suggests a void. Examining this same void in the UK, Reid and Ross suggest that the absence of such a right means there is no forum for individual rights or broad statements of objectives in relation to the environment.17 Without a constitutional right, what exists is "a patchwork of detailed provisions relating to individual authorities and their specific powers and duties" but no "law of general application" to provide a coherent set of rights, responsibilities and goals.18

It is easy to recognize that this same "patchwork" exists in the Canadian legal regime without express

${ }_{12}$ lbid., 38 .

${ }_{13}$ Boyd, The Right to a Healthy Environment, 5. supra note 2 at 5 .

${ }_{14}$ May and Daly, Global Environmental Constitutionalism, 49.

${ }_{15}$ Boyd, The Right to a Healthy Environment, supra note 2 at 18.

${ }_{16}$ Ibid., 18- 19.

${ }_{17}$ May and Daly, Global Environmental Constitutionalism, supra note 11 at 36. recognition by the supreme law of the land. Environmental constitutionalism offers itself as a standard to ensure and promote the complementarity of these differing regimes working at various levels of governance. It is thus only through constitutionalizing the right to a healthy environment that meaningful environmental protections can be afforded to Canadians.

Critics often point to the challenge of making constitutional amendments when determining the unviability of establishing this environmental right. Though such change would come with challenges, it should be remembered that the Constitution has been amended 11 times since 1982, including two revisions to the Charter.19 This means that changing the constitutional default is far from impossible.

\section{What Is the Right to a Healthy Environment?}

The right to a healthy environment is envisaged to ensure access to clean air, safe water, nutritious food, fertile soil, and conserve ecosystem functions and biological diversity.20 Scholars Hughes and lyalomhe propose that, at minimum, the right means the basic survival of humanity.21 They suggest three dimensions to this right: a quantitative, qualitative and temporal dimension.22 The quantitative dimension involves consideration of basic human needs such as sufficient supplies of air, water, food and shelter; the qualitative dimension holds that these supplies be safe, or at least uncontaminated and reasonably clean; and lastly, the temporal dimension insists that these supplies be sustained over generations.23 Attaining a level of environmental health that ensures basic human survival is thus what is often referred to as the "right to a reasonable level of environmental quality." ${ }_{24}$ Conceptualizing this as an individual right (rather than one held by the human collective) is how the "right to a healthy environment" is conceived.

Within the Canadian context, however, merely maintaining a minimum level of environmental quality is inadequate. Social expectations demand far more than just survival. In fact, despite the omission of a constitutional right, an overwhelming majority of Canadians hold environmental protection as a fundamental value. 25 This suggests that the substantive content of the right to a healthy environment must exceed the ecological minimum.

Boyd submits that in practice, the right to a healthy environment includes both a substantive right to

${ }_{19}$ David Boyd, "An Environmental Bill of Rights," LawNow Magazine, 28 February 2013.

${ }_{20}$ Boyd, The Right to a Healthy Environment, supra note 2 at 1.

${ }_{21}$ Hughes and lyalomhe, supra note 7 at 235.

${ }_{22} \mathrm{lbid}$.

${ }_{23} \mathrm{lbid}$.

$24 \mathrm{lbid}$.

${ }_{25}$ Boyd, The Right to a Healthy Environment, supra note 2 at 4 . 
environmental quality, as well as a collection of procedural safeguards to guarantee it. 26 These procedural safeguards include individual and collective rights to information, participation in decision-making and legal standing to seek remedies for violations. 27 The right necessarily establishes a corresponding obligation on governments to respect and protect healthy environments, or be held accountable.

Like all rights and freedoms guaranteed under the Charter, the right to a healthy environment would be balanced with competing rights. This means that it would not be absolute.28 Composing an exact list of the positive measures required to secure this right would be impossible due to the changing nature of our biological processes and scientific uncertainty; however, one can conceive that ensuring climate stability, protecting water sources, preserving biological diversity, maintaining soil fertility and protecting people from toxic contaminations are but a few of the basic protections which would be afforded by this right.

\section{Is the Right to a Healthy Environment a Human} Right?

The right to a healthy environment is sometimes thought to confound traditional categories of human rights. 29 This is based on the fact that such a right is both a negative, liberty-based right (i.e.: to protect individuals from unwarranted state interference) and a positive, welfarebased right (i.e. it requires the state to act and expend resources). 30 It can also be conceived as both a collective and individual right, a substantive and procedural right. These multiple aspects have prompted the question of whether the right to a healthy environment is yet a human right and, based on this query, what the corresponding significance that its global status has on constitutionalizing it in Canada.

When the "right to health" was first articulated in an international document as part of the International Covenant on Economic, Social and Cultural Rights (ICESCR) in 1966, no one predicted that environmental degradation would be a source of severe human health concern globally.31 In spite of this lack of foresight, the right to health is now an established piece within various international human rights regimes. The United Nations (UN) has since clarified the definition of this right:

\section{$4[\ldots]$ the right to health embraces a wide range} of socio-economic factors that promote

\footnotetext{
26 Boyd, The Right to a Healthy Environment, supra note 2 at 2.

${ }_{27} \mathrm{lbid}$.

$28 \mathrm{lbid} .3$.

$29 \mathrm{lbid}$.

30 Ibid.

${ }_{31}$ Stephen J. Turner, A Global Environmental Right (Routledge Explorations in Environmental Studies: New York, 2014), 19.
}

conditions in which people can lead a healthy life, and extends to the underlying determinants of health, such as food and nutrition, housing, access to safe and potable water and adequate sanitation, safe and healthy working conditions, and a healthy environment. 32

The clarification of this definition has meant greater inclusion of environmental factors within the ICESCR's reporting requirements and has seen an increase in the number of complaints founded on the adverse effects of environmental degradation.33

A formal articulation of a right to a clean environment then occurred at the 1972 UN Conference on the Human Environment. The Stockholm Declaration which emerged from this global conference, did not expressly recognize a right to the environment, but "Principle 1 " proclaimed:

[M]an has the fundamental right to freedom, equality and adequate conditions of life, in an environment of a quality that permits a life of dignity and well-being, and he bears a solemn responsibility to protect and improve the environment for present and future generations.34

The linkages between environmental degradation and adverse human health consequences thus emerged at the international level. Nevertheless, the question then becomes: is the right to a healthy environment an accepted "new" human right? While it remains true that international law has not yet incorporated an independent right to environmental quality, 35 this does not necessarily mean that the right does not exist.

There are numerous definitions of what constitutes a "human right". This means that reaching general agreement upon qualifying new rights has proved problematic. An early characterisation accepted that three defining characteristics needed to be present: that it be universal, moral and essential. 36 Boyd asserts that the right to a healthy environment meets each of these requirements since it is held by all persons; it exists whether or not the

${ }_{32}$ Committee on Economic, Social and Cultural Rights, General Comment 14, The Right to the Highest Attainable Standard of Health (Twentysecond session, 2000), UN Doc E/C.12/2000/4 (2000).

${ }_{33}$ Turner, A Global Environmental Right, supra note 32 at 19.

${ }_{34}$ Report of the UN Conference on the Human Environment, UN Doc A/CONF. 48/14/Rev. 1/Corr. 1 (1973) 3 at 4.

35 Jamie Benidickson, Environmental Law, (Publications for Professionals: Concord, ON, 1997) at 39.

36 M. Cranston, What Are Human Rights? (Bodley Head: London, 1973). 
nation, government or legal system recognizes it; and it ensures the dignity and quality of life of all people. 37

A further list of criteria were proposed by P. Alston, and have found general acceptance within the human rights community. Alston held that any recognized right should:

- Reflect a fundamentally important social value;

- Be relevant, inevitably to varying degrees, throughout a world of diverse value systems;

- Be eligible for recognition on the grounds that it is an interpretation of UN Charter obligations, a reflection of customary law rules or a formulation that is declaratory of general principles of law;

- Be consistent with, not merely repetitive of, the existing body of international human rights law;

- Be capable of achieving a very high degree of international consensus;

- Be compatible or at least not incompatible with the general practice of states; and

- Be sufficiently precise as to give rise to identifiable rights and obligations. 38

From this list of criteria, we see that the source and nature, procedural and substantive elements, and public acceptance of a "new" right are related to its legitimate formulation. Also significant is the reality that recognizing rights is largely a political exercise - dependent on a community being able to identify its own values and acknowledge its moral identity as a collective. If consensus cannot be reached or the political will does not exist, the potential for creating a new right is thus diminished.

In an article published in 1990, Gibson found that the right to a clean environment had not yet met Alston's criteria. She declared that to "prematurely view it as such" would be "detrimental to the integrity and standing of the human rights movement in general." 39 More than two decades have passed since Gibson made this declaration, yet both international and national concern and consensus related to environmental degradation (and its linkages to adverse human health) have increased dramatically.

In spite of her own conclusion, Gibson asserts that just because a clean environment is not a "right" based on our human membership, it is still a right because we are within an ecology.40 The failure of the right to a healthy environment to be recognized as a human right does not necessarily signal the demise of the right. Not all established rights are in fact formally recognized human rights. Constitutional rights, for example, are held by humans but are not necessarily human rights. ${ }_{41}$ So, while growing international acceptance of a human right to a healthy environment may lend support to the overall legitimacy and political will of achieving this right, it is not an imperative component to it receiving constitutional status in Canada.

A concession must be made that global recognition of a right does not necessarily mean substantive or even procedural protection for Canadians. Although human rights are designed to be universal (and Canada long-ago ratified the 1966 ICESCR 42 ), the precise obligations owed to rights holders and the related enforcement of these rights when violations occur are limited without codification in Canada. This further supports the proposition that although international recognition of the right of a healthy environment may lend legitimacy and support to the constitutionalization of the right to a healthy environment in Canada, this right should receive Charter status regardless of whether or not it is a recognized human right.

\section{Part II: The Sarnia Experience}

As mentioned, the right to a healthy environment can encompass many things. Air quality and the cumulative effects of airborne pollutants from industrial facilities is an issue of particular concern for residents of cities across Canada. Accordingly, a constitutionalized right to a healthy environment would be of specific benefit to residents who find the quality and cleanliness of their environments compromised by industrial pollutants.

A recent action highlighting the effects of industrial pollution and the need for the right to a healthy environment is a Notice of Application filed to the Ontario Divisional Court by two residents of Sarnia, Ontario. The applicants, Ada Lockridge and Ronald Plain, commenced the action in response to the excessive exposure of pollutants they face from nearby industrial facilities. The application seeks judicial review of a decision by the Ontario Government to approve additional pollutant releases. 43

Filed in October 2010 and amended in 2012, the Lockridge and Plain are now awaiting trial. Ecojustice is legal

\footnotetext{
${ }_{37}$ Boyd, The Right to a Healthy Environment, supra note 2 at 2.

38 P. Alston, "Conjuring Up New Human Rights: A Proposal For Quality Control," American Journal of International Law 78, no. 3 (1984): 614-15.

${ }_{39}$ Gibson, "The Right of a Clean Environment," supra note 8 at 10.

40 lbid., 11 .
}

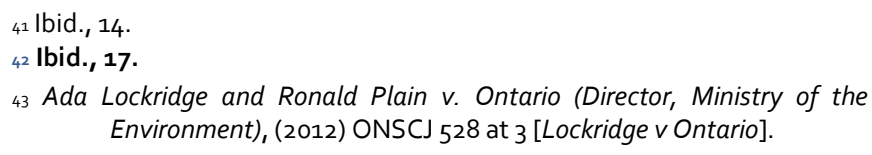
Environment), (2012) ONSCJ 528 at 3 [Lockridge v Ontario]. 
counsel to the applicants and sees the application as a step towards recognition of the right to a healthy environment. 44

\section{The Chemical Valley}

The Lockridge and Plain are members of the Aamjiwnaang First Nation on Sarnia 45 Indian Reserve. The community is situated at the heart of a heavily industrialized area commonly known as "The Chemical Valley" due to the overabundance of petrochemical facilities, refineries and energy production enterprises. There are 46 facilities within 25 kilometres of the Reserve.45 Lockridge resides 1.4 kilometres from a petroleum facility (owned and operated by Suncor Energy Products), with another 11 facilities located within a 15 kilometre radius of her home.46 Although spending most of his life as a resident of Aamjiwnaang, Plain recently moved off the Reserve because of fear of adverse health effects.47

Data from the Canadian National Pollution Release Inventory found that the industrial facilities in this area released 131,992 metric tonnes of air pollutants in 2005 confirming that Aamjiwnaang residents are in the midst of the heaviest air pollution load in all of Ontario. 48 Facilities regularly emit hydrogen sulphide, sulphur dioxide, carbon monoxide, oxides of nitrogen, particulate matter and benzene into the atmosphere. 49
44 See Ecojustice's "Right to Healthy Environment" campaign for more information: defended-their-right-to-fight-for-clean-air/

${ }_{45}$ Mary Ann Colihan, "Chemical Valley: Aamjiwnaang First Nation in Sarnia Sounds Alarm Over Toxins," CBC News, 1 April 2008. Access March 18 , http://www.cbc.ca/news2/background/aboriginals/health.html

${ }_{46}$ Environmental Law Centre Society, "Environmental Rights: Human Rights and Pollution in Sarnia's Chemical Valley," Environmental Law Centre (University of Victoria, ELC Associates' Program) 13 June 2012, 3.

\section{Lockridge v Ontario}

The Notice of Application challenges a 2010 decision made by the Director of the Ontario Ministry of the Environment to permit Suncor to increase its production by 25 percent. This permit would allow the facility to increase its releases to up to 180 tonnes of sulphur per day, an amount in excess of the Regulation's standards and in direct obstruction of the Ministry's 2008 decision to cap Suncor's emissions at 145 tonnes per day. $5^{0}$ The applicants point out that this permit is merely the latest in a long-history of approvals for contaminant emissions at the surrounding facilities. In allowing this increase, the Director is permitting additional pollutants to an area that already contains contaminants at a level hazardous to human health.

The Director and Minister are the primary regulators of air pollution in Ontario, authorized pursuant both the Environmental Protection Act $_{51}$ (EPA) and the OEBR. The EPA prohibits the discharge of contaminants that may cause an adverse effect but exempts discharges approved by the Director when they believe such effects are unlikely. $5^{2}$ Otherwise unlawful releases are therefore permitted by the Director by issuing permits or Director's Orders pursuant to this discretionary power. 53

Air pollutant regulatory standards are established under the EPA's Air Pollution - Local Air Quality standard (known as "POI" for "point of infringement standards). The EPA currently confers discretion on the Director for issuing permits (through the POI's limit on pollutant concentrations) above the regulated standards and regardless of whether a facility's operations are isolated or surrounded by other major facilities emitting similar and/or other regulated pollutants. This latter issue is the crux of the environmental problem in Sarnia's Chemical Valley. Since the EPA does not expressly require consideration of the cumulative effects of pollution before a control order is issued, residents are denied the right to a healthy environment on account of the combined emissions in a concentrated area.

\section{An Implicit Challenge to Gain Explicit Recognition}

Lockridge and Plain challenge the process for issuing permits and Director's orders under the EPA. They seek remedies under section 52 of the Constitution to declare

${ }_{47} \mathrm{lbid}$.

48 Elaine MacDonald and Sarah Rang, "Exposing Canada's Chemical Valley" (Toronto: Ecojustice, 2007), 11.

49 Environmental Law Centre Society, "Environmental Rights: Human Rights and Pollution in Sarnia's Chemical Valley," supra note 46 at 3.

50 Lockridge v. Ontario, supra note 43 at 4.

${ }_{51}$ RSO 1990, c E.19.

${ }_{52}$ May and Daly, Global Environmental Constitutionalism, 49. su

${ }_{53}$ Gibson, "The Right of a Clean Environment," 9. . 
these provisions inoperative to the extent that they violate their Charter rights. They assert that the Director's approval of more pollutant releases infringes their right to life, liberty and security of the person guaranteed by s. 7 and their equality rights under S. 15(1). They claim a remedy under s. $24(1)$ to the extent that the Director failed to take the cumulative effects of these toxic releases into account.

As will be discussed further in Part III, s. 7 is triggered when government action causes serious risks to physical or mental health. ${ }_{44}$ The applicants have a strong case to surpass this hurdle given that the adverse health consequences of breathing Chemical Valley's polluted air are enormous. Among the list of medical conditions suffered by Aamjiwnaang residents are high rates of asthma (22 percent of children and 17 percent of adults), miscarriages, birth defects, skin rashes, high blood pressure, chronic headaches and cancers. 55

The community also suffers a skewed birth ratio where there are more female births than male. A study published in Environmental Health Perspectives found that between 1999 and 2003 only 33 percent of babies born in the community were male, and only 41 percent if averaged over ten years.56 Adverse mental health impacts are also purported from constantly living in fear of the smokestacks, smells and sirens associated with accidental contaminant releases. 57

As for the s. 15(1) claim, the test to establish a violation of equality requires that the law creates a distinction based on enumerated or analogous grounds, and that this distinction creates a disadvantage by perpetuating prejudice or stereotypes. ${ }_{5}$ Lockridge and Plain challenge this on the ground that Aboriginal peoples living on reserve belong to a group that has faced "historic, economic, social, health, and cultural disadvantage in Canadian society." Based on their distinct cultural connection to the Reserve, and "by virtue of being a member of the Applicant's placeand culturally based community," ${ }^{60}$ heightened exposure to air pollutants under the EPA's discretion to the Director perpetuates this disadvantage. They also argue that the Director's decision perpetuates prejudice against their right to practice their distinct culture since the decision compromises their ability to practice cultural activities in the outdoors and risks the health of future generations.

\footnotetext{
${ }_{54} R$ v. Mortgentaler [1988] 1 SCR 30; Chaoulli v. Quebec (Procurer General) 2005 SCC 35.

${ }_{55}$ Lockridge v. Ontario, supra note 43 at 14.

${ }_{56}$ Constanze Mackenzie, Ada Lockridge, and Margaret Keith, "Declining Sex Ratio in a First Nation Community," Environmental Health Perspectives 113, no. 10 (2005):1295-1298; CBC News, "Aamjiwnaang First Nations Concerned About Chemical Exposure"

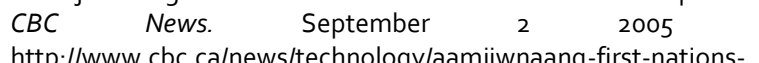
http://www.cbc.ca/news/technology/aamjiwnaang-first-nationsconcerned-about-chemical-exposure-1.553954
}

Lockridge and Plain present a strong challenge on account of the combined adverse physical and mental health impacts and the Director's failure to consider the cumulative effects of pollution in the area. This decision effectively forces residents to choose between maintaining their community and culture, and their personal autonomy through the control of their health and well-being.61 If the Court accepts that one or both of their Charter rights have been infringed, there is the possibility that an implicit right to a healthy environment would be recognized. This application is therefore an attempt to have an implicit environmental right recognized in existing Charter provisions in order that explicit recognition of the right of a healthy environment is achieved. As will be discussed further below, however, given the judiciary's reluctance to recognize this implicit right, the likelihood of this occurring is uncertain.

\section{Part III: Gaps in the Legal Framework}

\section{A Legislative Basis for Environmental Rights}

Notwithstanding the incomplete constitutional status of the right to a healthy environment, environmental protection in Canada is not entirely lacking. Federal, provincial and local governments can legislate environmental rights. This is typically performed through an environmental bill of rights (EBR) statute. Ontario, Quebec, the Yukon, the Northwest Territories and Nunavut have each legislated an EBR offering some substantive protections for environmental wrongs. No EBR currently exists at the federal level, but Bill C-634 was recently proposed in an effort to create a federal citizen rights-based EBR.

\section{The Ontario Environmental Bill of Rights}

Ontario's OEBR 62 is a complex statute that requires the provincial government to consult the public on almost all environmental decisions. Passed in 1993, the stated purpose of the Act is to "protect, conserve and, where reasonable, restore the integrity of the environment; ${ }_{63}$ to "provide sustainability of the environment;" 64 and, notably, to "protect the right to a healthy environment." 65

Despite these express objectives, the OEBR is primarily designed to increase public participation in environmental decision-making.66 This means that the mechanisms for enforcement focus on involving citizens in

${ }_{57}$ Lockridge v. Ontario, supra note 43 at 14 .

${ }_{58} R$ v. Kapp, 2008 SCC 41.

${ }_{59}$ Lockridge v. Ontario, supra note 43 at 15.

6 Ibid. at 6.

$6_{1}$ lbid. at 15 .

${ }_{62}$ OEBR, supra note 5 .

$6_{3}$ Ibid. at s. $2(1)(a)$.

64 lbid. at s. $2(1)(b)$

${ }_{65}$ lbid. at s. $2(1)(c)$.

66 Hughes and lyalomhe, supra note 7 at 250. 
administrative processes, rather than giving them substantive legal standing. Critics have argued that its objective of providing Ontarians with the right to a healthy environment is "limited to a statement of legislative intent, rather than a substantive and legally enforceable right." 67 The rights conferred under this Act are, accordingly, largely procedural.

Though limited in providing substantive rights, the Act does afford citizens legal standing to commence judicial proceedings on two grounds. First, s. 84 establishes the right for a resident to bring a cause of action where "the actual or imminent contravention [of the Act] has caused or will imminently cause significant harm to a public resource."68 The Act defines "public resource" to be air, water, public land, and any plant or animal life associated with these ecological systems. 69 This provision thus acts as a type of statutory tort.

The hurdles, which must be overcome before an action may be commenced under s. 84 , are extensive. A claimant must have exhausted the right to have an investigation performed under s. 74 of the Act, and that investigation must have concluded that the contravention be unreasonable.70 The Minister must then be of the opinion that the contravention is "not likely to cause harm to the environment." ${ }_{71}$ Additional limitations on the action include the fact that the outcome of the investigation is discretionary ${ }_{i 72}$ class actions are forbidden; $; 73$ and, even if a claimant is successful, damages are not available as an award.74

The second means of gaining standing under the OEBR is through s. 103. This section provides for the right of an individual to bring an action upon suffering "direct economic loss or personal injury as a result of a public nuisance that caused harm to the environment." 75

There have been some successful prosecutions using this framework; however, the OBER is largely underutilized. More than a decade after its enactment, s. 84 has only been used twice and s. 103 only six times (with the majority of actions not proceeding past the certification stage). 76 Benidickson points out that such avenues are costly and difficult; consequently, "[t]he weak-spirited need not even try." 77

The legislative protections provided by the OEBR are clearly limited. The only real rights conferred on citizens are rights of notice, rights to comment, and the right to have

\footnotetext{
${ }_{67}$ M. Winfield, G. Ford \& G. Crann, Achieving the Holy Grail? A Legal and Political Analysis of Ontario's Environmental Bill of Rights (Toronto: C.I.E.L.A.P., 1995) at 11.

${ }_{68}$ OEBR, supra note 5 at s. 84(1).

${ }_{69}$ lbid. at s. $82(a)-(e)$.

70 lbid., at s. 84(2).

${ }_{71}$ lbid. at S. $77(2)$

72 lbid. at s. 80.

$73 \mathrm{lbid}$. at s. $84(7)$.

$74 \mathrm{lbid}$. at s. 93(2).
}

these comments considered within the administrative decision-making process.78 Furthermore, a failure to respect these "rights" does not invalidate those decisions. Sufficient legal recourse to protect an individual's right to a healthy environment is hardly even imagined in the Act.

In $R \vee$ Canadian Pacific $L t d_{79}$ the court analyzed the OBER and remarked on the interpretation of environmental legislation in general. This case concerned a charge under $\mathrm{s}$. 13 of the OBER, with CP challenging the violation on the ground that aspects of the provision were so vague and broad that it "failed to establish a standard of sufficient intelligibility to allow citizens to regulate their conduct." 80 Specifically, the railway challenged the use of the terms contamination, impairment, natural environment, and the expression "for any use that can be made of it." 81

Gonthier J., writing for six members of the Supreme Court, found that the legislative provisions passed the vagueness challenge. Interestingly, in his analysis, Gonthier J. remarked that in the environmental protection context, "a strict requirement of drafting prevision might well undermine the ability of the legislature to provide for a comprehensive and flexible regime." 82 This declaration suggests that precise codification of environmental hazards may actually obstruct rather than support an understanding of the prohibited conduct. He explained his view of the legislative options as such:

In the area of environmental protection, legislators have two choices. They may enact detailed provisions which prohibit the release of particular quantities of enumerated substances into the natural environment. Alternatively, they may choose a more general prohibition of "pollution" and rely on the courts to determine whether, in a particular case, the release of a substance into the natural environment is of sufficient magnitude to attract legislative sanction. The latter option is, of course, more flexible and better able to accommodate developments in our knowledge about environmental protection.

$75 \mathrm{lbid}$, at S. 103(1).

${ }_{76}$ Benidickson, supra note 36 at 417 .

$77 \mathrm{lbid}$. at 127.

78 Hughes and lyalomhe, "Substantive Environmental Rights in Canada," supra note 7 at 252 .

${ }_{79} R$ V Canadian Pacific Ltd., [1995] 2 SCR 1028.

80 lbid. at 1073 .

$81 \mathrm{lbid}$.

$82 \mathrm{lbid}$.

University of Saskatchewan Undegraduate Research Journal 
This declaration further supports the need for an explicit right to a healthy environment. It confirms the limits of provincial legislation in its efforts to protect environmental rights. It also speaks to the fact that, falling into Gonthier J.'s second category, a constitutional environmental right offers a general prohibition against actions or forbearance that have adverse effects on human health, which are thus better able to adjust and develop in accordance with our knowledge of environmental protections.

\section{Bill C-634: A Federal Environmental Bill of Rights}

A major limitation of provincial EBRs is the fact that they can only legislate over matters falling within provincial jurisdiction. This includes authority over powers such as building codes, mining, forestry, and electricity generation. 83 A federal EBR, on the other hand, could include environmental protections over matters falling within federal authority. This would extend statutory protection to areas such as fisheries and oceans, airports, transportation, telecommunication, and interprovincial pipelines. 84

Tabled as a private member's bill in 2009, Bill C-634, An Act to Establish a Canadian Environmental Bill of Rights 85 was drafted by environmental organizations in an effort to create a federal citizen rights-based EBR. The vision for the Bill was described by sponsoring NDP MP Linda Duncan:

The bill, once enacted, would impose critical duties and extend important rights by, first, enshrining the right in Canadians to a healthy and ecologically balanced environment, including through amendment of the Canadian Bill of Rights; second, by legally enshrining the government's public trust duty to protect the environment to the extent of its jurisdiction, including legislating and enforcing environmental protection laws; and third, by extending to Canadians the right to hold their government accountable through access to environmental information, participation in decisionmaking impacting their environment, and legal standing to seek judicial intervention where those rights are denied. 86

${ }_{83}$ Pierre Sadik, "Making Sense of the Proposed Environmental Bill of Rights," Ecojustice Online. Accessed 18 March 2015. http://www.ecojustice.ca/making-sense-of-the-proposedcanadian-environmental-bill-of-rights/

84 lbid.

85 "Legisinfo: C-634, An Act to Establish a Canadian Environmental Bill of Rights," supra note 6 . .

86 "Bill C-634: Canadian Environmental Bill of Rights", openparliament.ca, $41^{\text {st }}$ Parliament, $2^{\text {nd }}$ Session. Accessed 20 March 2015.
The motion for Bill C-634 was adopted and the Introduction and First Reading completed on 29 October 2014.87 The Bill now awaits Second Reading.

The first and most notable purpose of the Bill is that it is meant to "[s]afeguard the rights of present and future Canadians to a healthy and ecologically balanced environment." 88 Another provision would give statutory recognition that "[e]very resident of Canada has a right to a healthy and ecologically balanced environment" and that "the Government of Canada has an obligation [...] to protect the right of every resident of Canada to a healthy and ecologically balanced environment." 89

The significance of these provisions becomes clear when examining the substantive and procedural avenues for legal standing to promote compliance with the Bill. Included is the right to sue the federal Crown for violating the right to a healthy and ecologically balanced environment, 90 as well as the right to sue private parties where a violation of federal law has caused "significant environmental harm." ${ }_{91}$ Further to these is the fact that constraints on commencing a judicial review related to environmental protection would be lessened.92

The creation of a federal EBR would thus go a long way to filling in some of the gaps in Canada's protection of the right to a healthy environment. Whether or not it receives Royal Assent by Parliament, this proposed Bill is another example of the growing support for an environmental right. The Bill's recognition of the right to a healthy environment stands as proof that the need for this right has surpassed the local and provincial level, and now extends to the federal level of government. It is only a matter of time before Canadians will demand that their right to a healthy environment receives the ultimate recognition by constitutional codification.

The Limits of an Implicit Right to the Environment No explicit constitutional right to the environment currently exists in Canada. This fact has not precluded arguments that the Charter contains provisions that implicitly acknowledge the existence of an environmental right. At least twenty nations around the world have followed this technique by ruling that the right to a healthy environment is an implicit element of the right to life. 93 Within the Canadian judicial context, this type of process is likewise not unheard of. For example in Egan $v$ Canada, 94 the Supreme Court

${ }_{87}$ "Legisinfo: C-634, An Act to Establish a Canadian Environmental Bill of Rights." supra note 6 .

$88 \mathrm{lbid}$., s. $6(\mathrm{a})$

89 Ibid., s. 9(2).

go lbid., s. 21.

${ }_{91}$ lbid., s. 23.

92 lbid., s. 22.

${ }_{93}$ Boyd, The Right to a Healthy Environment, supra note 2 at 86. ${ }_{94}$ [1995] 2 SCR 513

University of Saskatchewan Undegraduate Research Journal 
accepted that sexual orientation was implicitly included in s. 15 of the Charter, thus establishing this as a new analogous ground to base discrimination. For those seeking to ground the right to a healthy environment, ss. 7 and 15 are the most promising provisions to ground constitutional recognition.

\section{Section 7}

Section 7 provides that "[e]veryone has the right to life, liberty and security of the person and the right not to be deprived thereof except in accordance with the principles of fundamental justice." $95 \mathrm{~A}$ two-stage test for the application of this section was developed in Reference Re S. 94(2) of Motor Vehicles Act:96 an appellant must demonstrate a deprivation of her right to life, liberty and security of the person, and then demonstrate that this deprivation occurred in a manner not consistent with the principles of fundamental justice.

The range of specific interests protected under this section continues to be under consideration by the courts. To date it has been recognized to include freedom from threats to one's physical and mental integrity (including risks to health), but excludes property and economic interests.97 Individuals exposed to physical or mental health risks due to environmental contamination or degradation, resulting from a decision of an institution subject to Charter application, may therefore envisage a challenge under this section.

Benidickson points out that any claim under this provision is dependent upon "satisfactory proof of a causal connection between the injury alleged and the impugned decision or official action." ${ }_{98}^{8}$ Therefore, while it seems logical that the intrusive presence of harmful substances in one's body would be a violation of the security of the person and possibly their life, the person's ability to prove this causal connection may be a difficult burden to meet. Depending on the severity and type of risk, the evidence available to that individual may be limited. Notably, this requirement also limits the possibility of this section encompassing a preventative claim related to the potential for adverse health risks - an issue of particular concern given that individuals should have the right to preserve their healthy environment as well as be provided with redress when this right is violated.

In Manicom $v$ County of Oxford, 99 landowners challenged the County of Oxford's decision (with approval by the Ontario Cabinet) to locate a waste disposal site within the Township of South-West Oxford. Residents argued that approval of this decision violated their rights under 5.7 since

\footnotetext{
${ }_{95}$ Charter, supra note 4 , at S. 7.

${ }_{96} \mathrm{lbid}$.

${ }_{97}$ See $R$ v Morgentaler [1988], 1 SCR 30; Chaoulliv Quebec (Procurer General), 2005 SCC 35; Victoria (City) v Adams, 2009 BCCA 563.

${ }_{98}$ Benidickson, supra note 36 at 40 .

99 (1985) 52 OR (2d) 137, 21 DLR $\left(4^{\text {th }}\right) 611$.

$100 \mathrm{lbid}$.
}

the Joint Board appointed to consider the environmental impacts of the site had concluded that the decision should be rejected. The Board advised against the decision on a number of environmental and health-related grounds. Most significant was the finding that because the soil was composed of sand, silt and gravel, it would create an "inordinately high risk of contamination of underground water by leachate from waste disposed on site." ${ }_{100}$ The Board concluded that such contamination would affect both the immediate site and the surrounding aquifers, which included domestic and agricultural water supplies. ${ }_{101}$ Residents clearly had much to fear in relation to maintaining the cleanliness of their hydrological systems and the corresponding health of residents.

The Divisional Court rejected the Plaintiffs' claim on the ground that property interests are not protected under $\mathrm{s}$. 7.102 One dissenting judge, however, declared that if a link could be demonstrated between their adverse health effects and the approval of the landfill (rather than property concerns), there would be a chance that they could demonstrate a s. 7 infringement.103 The inclusions of this opinion is thus significant as it presents the possibility of future environmental claims under this section.

Claimants again attempted to use this section to preserve their right to a healthy environment in Energy Probe $\checkmark$ Canada. $_{104}$ In this case it was argued that a statutory compensation scheme established under the federal Nuclear Liability Act, 105 which limited the liability for victims of nuclear accidents, infringed their section 7 right to security of the person. ${ }_{106}$ Since this limited liability resulted in a proliferation of nuclear reactors and a reduced incentive on nuclear operators to act safely, the Plaintiffs argued that the scheme infringed the security of the person. However, this challenge was likewise dismissed.

101 lbid.

102 Benidickson, supra note 36 at 41 .

${ }_{103}$ lbid.

104 (1994), 17 OR (3d) 717 (Gen Div).

${ }_{105} \mathrm{RSC}, 1985$, c N-28.

${ }_{106}$ Benidickson, supra note 36 at 42 . 


\section{Section 15}

Section 15(1) of the Charter provides that "[e]very individual is equal before and under the law and has the right to the equal protection and equal benefit of the law without discrimination and, in particular, without discrimination based on race, national or ethnic origin, colour, religion, sex, age or mental or physical disability." ${ }_{107}$ Quoting Haig v Canada:108

A complainant under s. 15(1) must establish that he or she is a member of a discrete and insular minority group, that the group is defined by characteristics analogous to the enumerated grounds of discrimination set out in 5. 15(1), and that the law has a negative impact. In determining whether a group is analogous to those that are enumerated within s. 15(1), of the Charter [a court must focus] on the larger context by searching for indicia of discrimination such as stereotyping, historical disadvantage or vulnerability to political and social prejudice. 109

This, among other recent cases, has consequently narrowed the scope of s. 15(1) by further requiring that the decision make a distinction based on enumerated or analogous grounds.

The applicability of this provision to environmental claims was first attempted in Aluminum Co. of Canada $v$ Ontario (Minister of Environment). 110 In this case, an aluminum company claimed that the regulations regarding refillable containers discriminated against them to the economic advantage of steel manufacturers.111 The Court held that economic distribution was not a recognized form of discrimination and, consequently, the company was not afforded protection under the equality provision.

The abovementioned case of Energy Probe $v$ Canada, Plaintiffs also made a s. 15 challenge. They argued that all residents in proximity to nuclear reactors suffered discrimination because they were most exposed to physical risk. Because the scheme limited their ability to seek financial compensation, they asserted that these residents - as potential victims of a nuclear accident - faced distinct discrimination compared to victims of other accidents.112 Wright $J$. did not find this argument convincing and found that "as that concept is understood within the meaning of the section" the scheme did not discriminate.113
In spite of the judiciary's reluctance to recognize an implicit environmental right in either s. 7 or s. 15(1), many lawyers and scholars continue to suggest that these provisions are broad enough to encompass the right to a healthy environment. In relation to s. 7, Dianne Save said, "If a healthy environment is a necessary precondition for human life and bodily integrity, then the human right to life and bodily integrity must entail a right to a healthy environment." ${ }_{114}$ However, these past failed attempts also affirm the judiciary's hesitation to recognize any such right without Parliament expressly providing for it. Expressly entrenching the right to a healthy environment in the Charter is thus the only way to protect and preserve the right of all Canadians to a clean environment.

\section{Conclusion}

The growing trend of environmental constitutionalism globally exemplifies the ultimate, most authoritative culmination of environmental protection efforts. Challenges faced by residents across Canada, and epitomized by Sarnians in the Chemical Valley, in combination with the judiciary's unwillingness to recognize an implicit right to the environment in existing provisions of the Charter, means that Canadians need an explicit recognition of their right to a healthy environment. If the existing legal framework is unable to protect this right, they will demand express recognition of it. Silence - as our constitutional default - is an inadequate response to the growing need for the right to a healthy environment to be codified. Changing this elusive nature is the next step in entrenching environmental constitutionalism in Canada.

\section{Addendum}

Since completion of this paper, Ada Lockridge and Ron Plain have withdrawn their claim against the Government of Ontario and Suncor Energy. Ecojustice points to increased government efforts to address the pollution crisis in the Chemical Valley as the impetus for a strategy change. They cite as evidence that the government is finally taking action Ontario's acknowledgement, for the first time, that the pollution crisis in Aamjiwnaang is unacceptable, and note that the former Environmental Commissioner Gord Miller called the situation "intolerable" in his 2014 annual report. Ecojustice also claims the Province has begun to improve the way it communicates with Aamjiwanaag about pollution. Despite what Ecojustice coins "remarkable progress," the

${ }_{111}$ lbid.

${ }_{112}$ Benidickson, supra note 36 at 42 .

${ }_{113}$ Ibid., 43.

${ }_{114}$ Boyd, The Right to a Healthy Environment, supra note 2 at 177 . 
reality is that the cumulative effects of air pollution remain unchanged in the Sarnia area, and we are no closer to constitutional recognition of the right to a healthy environment. See Ecojustice's full explanation here for withdrawing the lawsuit here: https://www.ecojustice.ca/changing-course-chemicalvalleyl 


\section{Bibliography}

Legislation

The Canadian Charter of Rights and Freedoms, Part I of the Constitution Act, 1982, being $=$ Schedule B to the Canada Act 1982 (UK), 1982, c 11.

Committee on Economic, Social and Cultural Rights, General Comment 14, The Right to the Highest Attainable Standard of Health (Twenty-second session, 2000), UN Doc E/C.12/2000/4 (2000).

Environmental Bill of Rights, 1993 SO1993, c 28.

Environmental Protection Act RSO 1990, c E.19.

Nuclear Liability Act RSC, 1985, c N-28.

Report of the UN Conference on the Human Environment, UN Doc A/CONF. 48/14/Rev. 1/Corr.

1 (1973) 3 .

Jurisprudence

Ada Lockridge and Ronand Plain v Ontario (Director, Ministry of the Environment), (2012) ONSCJ 528.

Aluminum Co. of Canada v Ontario (Minister of Environment) (1980), 115 DLR (3d) 495.

$R v$ Canadian Pacific Ltd., [1995] 2 SCR 1028.

Egan v Canada, [1995] 2 SCR 513.

Energy Probe v Canada (1994), 17 OR (3d) 717 (Gen Div).

Haig v Canada (Chief Electoral Officer), [1993] 2 SCR 995

R. v. Kapp, 2008 SCC 41.

Manicom v County of Oxford (1985) 52 OR (2d) 137, 21 DLR $\left(4^{\text {th }}\right) 611$.

\section{Secondary Materials}

Alston, P., "Conjuring Up New Human Rights: A Proposal for Quality Control" (1984) 78 Am. J. Int'l L. 607.

Benidickson, Jamie, Environmental Law, (Publications for Professionals: Concord, ON, 1997).
"Bill C-634: Canadian Environmental Bill of Rights", openparliament.ca, $41^{\text {st }}$ Parliament, $2^{\text {nd }}$ Session. Accessed 20 March 2015.

Boyd, David, "An Environmental Bill of Rights", LawNow Magazine, 28 February 2013.

Boyd, David, The Right to a Healthy Environment: Revitalizing Canada's Constitution (UBC Press, Vancouver: 2012), at 88.

Cranston, M., What Are Human Rights? (Bodley Head: London, 1973).

Environmental Law Centre Society. "Environmental Rights: Human Rights and Pollution in Sarnia's Chemical Valley", Environmental Law Centre (University of Victoria, ELC Associates' Program) 13 June 2012.

Gibson, Noralee, "The Right of a Clean Environment", Saskatchewan Law Review (1990), Vol 54, No 5.

Hughes, Elaine and David lyalomhe, "Substantive Environmental Rights in Canada", Ottawa Law Review (1998-99), Vol 30:2.

"Legisinfo: C-634, An Act to Establish a Canadian Environmental Bill of Rights", Parliament of Canada, 41 $1^{\text {st }}$ Parliament, $2^{\text {nd }}$ Session [C-634].

MacDonald, Elaine and Sarah Rang, "Exposing Canada's Chemical Valley" (Toronto: Ecojustice, 2007)

May, James R. and Erin Daly, Global Environmental Constitutionalism, (Cambridge University Press: New York, 2015)

Sadik, Pierre, "Making Sense of the Proposed Environmental Bill of Rights", Ecojustice Online. Accessed 18 March 2015.

Schochet, Gordon J., "Introduction: Constitutionalism, Liberalism, and the Study of Politics," in Nomos XX:1, edited by J. Roland Pennock and John W. Chapman (New York University Press, 1979).

Turner, Stephen J., A Global Environmental Right, (Routledge Explorations in Environmental Studies: New York, 2014).

Winfield, M., G. Ford \& G. Crann, Achieving the Holy Grail? A Legal and Political Analysis of Ontario's Environmental Bill of Rights (Toronto: C.I.E.L.A.P., 1995). 
